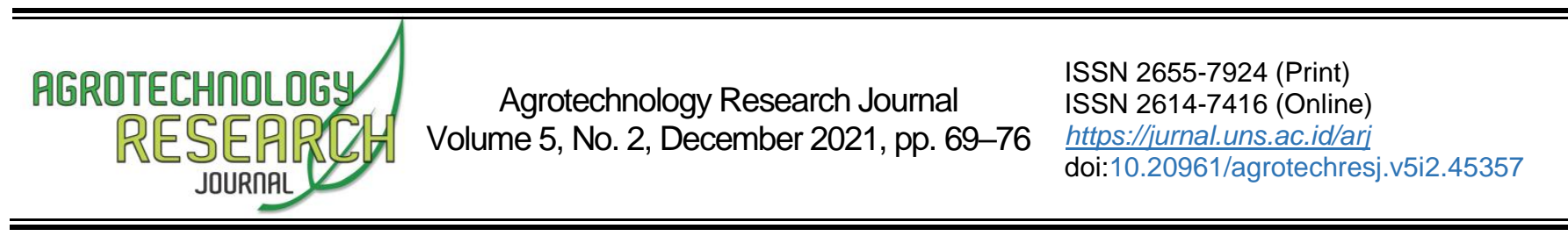

\title{
Tanggapan Morfologis dan Fisiologis Jagung Varietas Lokal Tambin terhadap Berbagai Pupuk Organik
}

\section{Morphological and Physiological Responses of Tambin Local Varieties of Corn to Various Organic Fertilizers}

\author{
Muji Rahayu ${ }^{1 *}$, Djoko Purnomo ${ }^{2}$, Andriyana Setyawati ${ }^{3}$, Edi Purwanto ${ }^{4}$, Amalia Tetrani Sakya ${ }^{5}$, Samanhudi ${ }^{6}$, \\ Ahmad Yunus $^{7}$, Gani Cahyo Handoyo ${ }^{8}$, Retna Bandriyati Arniputri ${ }^{9}$, Satya Primasasta Zulhivan ${ }^{10}$ \\ ${ }^{1-10}$ Department of Agrotechnology, Faculty of Agriculture, Universitas Sebelas Maret, Surakarta, Jawa Tengah 57126, Indonesia
}

Received 02 November 2020; Accepted 28 May 2021; Published 31 December 2021

\begin{abstract}
Food crops of local varieties are solutions to realize national food security. To boost the production of local corn varieties, various organic fertilizer is promising to develop. This research aimed to study the morphological and physiological response of local variety corn Tambin. The research used a completely randomized design (CRD) one factor with seven treatments: various fertilizers. Various fertilizers consist of no organic fertilizer, liquid organic, compost, cow manure, rabbit urine, chicken manure, and goat manure. The results showed that the application of various organic fertilizers did not affect morphological characters of the local variety of corn Tambin. In This study, the application of various organic fertilizers did not affect the morphological character of corn, including the height of the plant, the number of leaves, the diameter of the stem, the length of the leaves, and the angle of Tambin corn leaves. Application of cow manure, compost, chicken manure, and goat manure could increase the leaf area aged 3 WAP (week after planting) by 716.13 - $1086.52 \mathrm{~g}$ per plant. In physiological character, the application of various organic fertilizers could not increase the net assimilation rate, relative growth rate, chlorophyll content, and the specific leave weight. The application of all organic fertilizers, except liquid organic fertilizer, increased the dry weight of plants at the time of harvest by $2.97-36.81 \mathrm{~g}$.
\end{abstract}

Keywords: cow manure; compost; chicken manure; goat manure; Zea mays

Cite this as (CSE Style): Rahayu M, Purnomo D, Setyawati A, Purwanto E, Sakya AT, Samanhudi, Yunus A, Handoyo GC, Arniputri RB, Zulhivan SP. 2021. Tanggapan morfologis dan fisiologis jagung varietas lokal Tambin terhadap berbagai pupuk organik. Agrotechnology Res J. 5(2):69-76. https://dx.doi.org/10.20961/agrotechresj.v5i2.45357.

\section{PENDAHULUAN}

Indonesia memiliki banyak varietas lokal jagung sebagai sumber plasma nutfah yang potensial untuk dikembangkan. Ketersediaan plasma nutfah yang besar, terutama varietas lokal memiliki arti penting secara genetik untuk sifat-sifat tertentu sehingga bisa digunakan untuk perakitan varietas unggul berdaya hasil tinggi dan tahan pada kondisi lingkungan tertentu yang kurang optimal (Amzeri 2009).

Penyebaran jagung (Zea mays L.) lokal diperkirakan kurang dari $25 \%$. Mayoritas jagung lokal ditanam di Madura (Jawa Timur), Nusa Tenggara Timur, dan Sulawesi Selatan (Amzeri 2018). Varietas lokal banyak dibudidayakan di beberapa daerah dan digunakan untuk menggantikan berbagai jenis lainnya seperti hibrida,

${ }^{*}$ Corresponding Author:

E-Mail': mujirahayu@staff.uns.ac.id komposit, maupun transgenik. Hal ini dilakukan untuk mengembangkan sumber genetik jagung lokal sehingga dapat menempati posisi sejajar dengan varietas unggul yang telah dirilis untuk meningkatkan produktivitas jagung di Indonesia melalui konsep pertanian berkelanjutan (Lesilolo 2012).

Salah satu jagung lokal yang banyak dibudidayakan adalah jagung lokal Madura varietas Tambin. Jagung Tambin memiliki potensi hasil relatif tinggi dibandingkan jagung lokal Madura lainnya, yaitu sekitar 3,37 -3,86 ton/ha. Keunggulan jagung lokal Madura adalah mempunyai daya simpan lama ( \pm 1 tahun) sehingga dapat digunakan sebagai cadangan makanan selama satu tahun (Amzeri 2018). Jagung lokal Madura juga memiliki kandungan protein dan lemak tinggi masingmasing 11,24\% dan 4,96 \% (Suhardjo dan Lestari 2006). Selain itu, butiran jagung Madura relatif kecil sehingga sesuai untuk pakan burung, dan harganya lebih mahal. Hasil pengolahan menjadi beras jagung Madura harganya lebih mahal dibandingkan jagung lainnya. Rasa jagung lokal juga lebih enak dan gurih 
sehingga masyarakat Madura enggan mengganti jenis usaha tani dari jagung lokal ke jagung hibrida (Amzeri 2018). Jagung Madura juga memiliki umur pendek sehingga menjadi pertimbangan penting petani Madura untuk menetapkan varietas jagung yang akan ditanam. Hal ini berkaitan dengan pergiliran tanaman yang cukup ketat karena rendahnya ketersediaan air tanah dan curah hujan (Arifin dan Fatmawati 2011).

Konsep pertanian berkelanjutan tidak menjadikan pupuk sintetis sebagai masukan utama sebagai nutrisi tanaman. Penggunaan pupuk dengan bahan yang lebih ramah lingkungan yaitu pupuk organik, baik melalui tanah maupun daun. Penggunaan pupuk organik memperbaiki sifat tanah dan menjaga ekosistem tanah dalam jangka panjang (Santosa 2012). Selain itu, kombinasi varietas lokal dan pemberian pupuk yang tepat berpotensi memberikan hasil tinggi sehingga akan memberikan peningkatan hasil produksi yang signifikan. Penggunaan pupuk organik juga dapat meningkatkan hasil dan produksi tanaman (Santosa 2012).

Penggunaan pupuk organik dalam budidaya tanaman telah banyak dilakukan. Beberapa hasil penelitian berkaitan dengan aplikasi pupuk organik memberikan hasil yang bervariasi. Menurut Adijaya dan Yasa (2014), aplikasi pupuk kandang sapi dosis 15 ton.ha-1 dan bio urine dosis 75.000 liter.ha-1 meningkatkan indeks panen sebesar 121,39\%. Pupuk organik cair Super ACl 1,43 ml.L-1 air pada jagung manis dapat meningkatkan produksi tongkol sebesar 8,77 ton.ha-1 (Rahmi dan Jumiati 2007). Aplikasi pupuk kandang kambing dosis 10 ton.ha ${ }^{-1}$ mampu meningkatkan hasil jagung manis sebesar 19,46\% dibandingkan dengan tanpa pemberian pupuk kandang kambing (Dinariani et al. 2010). Pemberian pupuk kandang 40 ton.ha ${ }^{-1}$ menghasilkan jumlah biji per baris yang paling banyak dan berbeda nyata dengan perlakuan tanpa pemberian pupuk (Leki et al. 2016). Pemberian pupuk kandang ayam sampai dengan dosis 6,5 ton.ha-1 memberikan pengaruh terbaik terhadap tinggi tanaman, jumlah daun dan panjang daun sorgum (Silalahi et al. 2018).

Berdasarkan uraian di atas, pemberian berbagai pupuk organik memberikan pengaruh yang beragam terhadap pertumbuhan dan karakter berbagai jenis tanaman. Namun demikian, penelitian berkaitan dengan tanggapan jagung varietas lokal Tambin terhadap pemberian berbagai pupuk organik belum banyak dilakukan. Penelitian ini bertujuan untuk mempelajari respons morfologis dan fisiologis jagung varietas lokal Tambin terhadap aplikasi berbagai pupuk organik.

\section{BAHAN DAN METODE}

Penelitian dilaksanakan pada bulan Juni hingga Oktober 2020. Percobaan menggunakan polybag di Rumah Kaca Fakultas Pertanian UNS, Surakarta yang berada pada ketinggian $110 \mathrm{mdpl}$ dengan koordinat 7³3'41.4"S 11051'32.3"E, sedangkan analisis laboratorium dilakukan di Laboratorium Fisiologi Tumbuhan dan Bioteknologi, serta Laboratorium Ekologi dan Manajemen Tanaman, Fakultas Pertanian Universitas Sebelas Maret (UNS).

Alat yang digunakan antara lain timbangan analitik, oven, spektrofotometer dan jangka sorong. Bahan yang digunakan adalah benih jagung lokal varietas Tambin, pupuk organik cair, pupuk urine kelinci, kompos, pupuk kotoran sapi, pupuk kotoran kambing, pupuk kotoran ayam, pestisida dan fungisida. Pupuk padat sudah berada dalam keadaan kering dan siap diaplikasikan ke pertanaman. Pupuk organik cair (POC) yang digunakan mengandung asam humat, asam fulvat, humin dan karbohidrat. Fungisida yang digunakan mengandung bahan aktif dimetomorf $50 \%$, sedangkan pestisidanya mengandung karbosulfan 5\%.

Benih jagung varietas Tambin, diberi perlakuan sebelum tanam yaitu direndam dengan menggunakan fungisida. Media tanam yang digunakan terdiri dari tanah dan pupuk organik (sesuai perlakuan). Penanaman menggunakan polybag ukuran tinggi dan diameter $30 \mathrm{~cm}$ x $30 \mathrm{~cm}$, dengan jarak antar polybag $25 \mathrm{~cm}$. Setiap polybag diisi dengan campuran tanah dan pupuk organik yaitu $7 \mathrm{~kg}$ tanah dan $700 \mathrm{~g}$ pupuk organik (sesuai perlakuan). Dosis ini mengacu pada Asrori et al. (2019), yang menyatakan penggunaan pupuk kandang pada $4 \mathrm{~kg}$ tanah adalah $400 \mathrm{~g}$ atau $1 \mathrm{~kg}$ tanah diberikan pupuk kandang sebesar $100 \mathrm{~g}$. Pupuk organik yang diberikan sesuai dengan masing-masing perlakuan. Pemupukan pupuk padat dilakukan pada saat persiapan media tanam namun untuk pupuk POC diaplikasikan 1 minggu sebelum tanam, sedangkan pupuk urine kelinci (80 ml.L-1 per tanaman) diaplikasikan pada 2 minggu setelah tanam (MST) dan diulang sampai muncul bunga jantan dengan interval satu minggu, disemprotkan pada atas dan bawah permukaan daun. Pupuk organik cair (POC) yang digunakan memiliki kandungan $22 \%$ asam organik dan 4\% Kalium. Selain pupuk organik, tanaman jagung Tambin juga diberikan pupuk anorganik, meliputi pupuk urea dengan dosis $300 \mathrm{~kg} \cdot \mathrm{ha}^{-1}$, SP-36 $100 \mathrm{~kg} \cdot \mathrm{ha}^{-1}$ dan $\mathrm{KCl} 100 \mathrm{~kg} \cdot \mathrm{ha}^{-1}$. Pupuk urea diberikan 3 kali yaitu 1/3 bagian pada saat tanaman umur 7 hari setelah tanam, $1 / 3$ bagian pada 25 HST, dan 1/3 bagian 35 HST. Pupuk SP-36 dan $\mathrm{KCl}$ diberikan sekali pada saat tanaman umur 7 HST.

Percobaan menggunakan rancangan acak lengkap (RAL) satu faktor dengan 7 perlakuan yaitu macam pupuk. Macam pupuk terdiri dari (a) tanpa pupuk organik, (b) pupuk organik cair (POC), (c) kompos, (d) pupuk kotoran sapi, (e) pupuk urine kelinci, (f) pupuk kotoran ayam dan (g) pupuk kotoran kambing. Setiap satuan perlakuan terdiri atas 4 pot (tanaman), masingmasing diulang 4 kali.

Variabel pengamatan meliputi: tinggi tanaman, pengukuran dilakukan mulai 2 MST sampai dengan 7 MST dengan interval seminggu sekali; Jumlah daun, pengukuran dilakukan pada 2 MST bersamaan dengan tinggi tanaman dengan interval seminggu sekali. Daun yang diukur adalah daun yang telah membuka sempurna; Luas daun, pengukuran luas daun dengan menggunakan metode gravimetri pada umur 3 dan 6 MST. Diameter batang, dilakukan pada 2 MST bersamaan dengan tinggi tanaman dengan interval seminggu sekali; Sudut daun, pengamatan sudut daun menggunakan busur penggaris pada posisi daun yang terletak pada satu daun di atas tongkol. Sudut daun diukur antara helaian daun di atas tongkol jagung dan batang. Pengamatan dilakukan pada umur 9 MST. 
Pengukuran kandungan klorofil menggunakan metode yang dikembangkan oleh Islam et al. (2009) yaitu dengan mengambil daun yang telah membuka sempurna sebanyak $1 \mathrm{~g}$, selanjutnya daun dihancurkan dalam mortar dan ditambahkan $20 \mathrm{ml}$ aseton $80 \%$. Larutan didiamkan beberapa saat, disaring dengan kertas saring Whatman no. 42. Filtrat dimasukkan ke dalam kuvet sampai garis batas kemudian diukur absorbansinya dengan spektrofotometer Shimadzu 1201 pada $\lambda 645$ dan $663 \mathrm{~nm}$. Penghitungan kandungan klorofil ditentukan dengan rumus sebagai berikut.

Kadar klorofil $\mathrm{a}=(12,7 \times \mathrm{A663}-2,69 \times \mathrm{A645}) \times$ $(20 \mathrm{ml} / 1000 \times 1 \mathrm{~g})$

Kadar klorofil $b=(22,9 \times A 645-4,68 \times$ A663 $) \times$ $(20 \mathrm{ml} / 1000 \times 1 \mathrm{~g})$

Kadar klorofil total $=(20,2 \times A 645+8,02 \times$ A663 $) \times$ $(20 \mathrm{ml} / 1000 \times 1 \mathrm{~g})$

Pengukuran bobot kering tanaman dilakukan sebanyak 3 kali yaitu pada 3, 6 dan 13 MST (saat panen). Sedangkan pengukuran Laju Asimilasi Bersih (LAB), menggunakan persamaan dari Syah et al (2003) sebagai berikut.

$$
L A B=\frac{(W 2-W 1)(\ln A 2-\ln A 1)}{(t 2-t 1)(A 2-A 1)}
$$

Dengan $\angle A B=$ Laju Asimilasi Bersih, $W_{1}=$ Bobot kering tanaman pada $t_{1}, A_{2}=$ Luas daun tanaman pada $t_{2}, W_{2}=$ Bobot kering tanaman pada $t_{2}, T_{1}=$ Waktu pada pengamatan pertama, $A_{1}=$ Luas daun tanaman pada $\mathrm{t}_{1}$, $T_{2}=$ Waktu pada pengamatan kedua.

Laju Pertumbuhan Relatif (LPR) dihitung dengan menggunakan persamaan dari Sitompul (2016) sebagai berikut.

$$
L P R=\frac{\ln W 2-\ln W 1}{t 2-t 1}
$$

dengan $\angle P R=$ Laju pertumbuhan relatif, $W_{1}=$ Bobot kering tanaman pada $t_{1}, t_{1}=$ Waktu pada pengamatan pertama, $W_{2}=$ Bobot kering tanaman pada $t_{2}$, dan $t_{2}=$ Waktu pada pengamatan kedua.

Data dianalisis menggunakan analisis ragam (ANOVA) dan jika berbeda nyata diuji lanjut dengan Duncan's Multiple Range Test (DMRT) taraf kepercayaan 95\% (Gomez AK dan Gomez AA 1995).

\section{HASIL DAN PEMBAHASAN}

Hasil penelitian ini menunjukkan bahwa aplikasi berbagai jenis pupuk organik tidak berpengaruh nyata terhadap tanggapan tinggi tanaman, jumlah daun, dan diameter batang jagung Tambin pada 7 MST (Tabel 1). Setiap pupuk organik memiliki kandungan unsur hara yang beragam, namun dalam penelitian ini aplikasi berbagai pupuk organik tidak meningkatkan pertumbuhan tanaman jagung varietas lokal Tambin. Tanaman jagung yang diaplikasi berbagai pupuk organik dan tidak diberikan pupuk organik menghasilkan tinggi tanaman, jumlah daun dan diameter batang yang tidak berbeda nyata.
Tabel 1. Tanggapan jagung varietas lokal Tambin terhadap pupuk organik pada tinggi tanaman, jumlah daun, dan diameter batang umur 7 MST

\begin{tabular}{lccc}
\hline Pupuk Organik & $\begin{array}{c}\text { Tinggi } \\
\text { Tanaman } \\
\text { (cm) }\end{array}$ & $\begin{array}{c}\text { Jumlah } \\
\text { Daun } \\
\text { (helai) }\end{array}$ & $\begin{array}{c}\text { Diameter } \\
\text { Batang } \\
(\mathrm{mm})\end{array}$ \\
\hline $\begin{array}{l}\text { Tanpa pupuk } \\
\text { organik }\end{array}$ & 201,6 & 11,00 & 17,83 \\
$\begin{array}{l}\text { Pupuk organik } \\
\text { cair }\end{array}$ & 207,3 & 13,25 & 16,54 \\
Kompos & 225,5 & 13,75 & 17,98 \\
Kotoran sapi & 208,0 & 13,25 & 17,37 \\
$\begin{array}{l}\text { Urine kelinci } \\
\text { Kotoran ayam }\end{array}$ & 194,8 & 12,63 & 17,74 \\
Kotoran kambing & 197,9 & 14,00 & 18,83 \\
\hline
\end{tabular}

Semakin bertambah umur tanaman, maka kebutuhan nutrisi yang dibutuhkan oleh tanaman untuk tumbuh dan berkembang juga semakin banyak. Aplikasi bahan organik berupa kompos, pupuk kotoran ayam, dan pupuk kotoran kambing ke dalam tanah, mampu menambah unsur hara yang diperlukan oleh tanaman terutama N. Menurut Safitri et al. (2017) aplikasi pupuk kotoran kambing hingga mencapai 40 ton.ha $^{-1}$ akan meningkatkan tinggi tanaman, bobot kering brangkasan, diameter tongkol, panjang tongkol, bobot tongkol per tanaman, bobot 100 butir dan bobot pipilan kering per petak. Hasil penelitian Fitriasari dan Rahmayuni (2017) menunjukkan bahwa pemberian urine kelinci konsentrasi 25 ml. L-1 air + pupuk anorganik 50\% memberikan nilai tertinggi pada parameter tinggi tanaman jagung manis $(118,83 \mathrm{~cm})$. Hal ini diduga karena ketersediaan unsur hara terutama Nitrogen $(\mathrm{N})$ yang terkandung dalam urine kelinci dapat diserap oleh akar tanaman dan digunakan untuk pertumbuhan tanaman.

Dalam penelitian ini, aplikasi pupuk kotoran ayam dapat menghasilkan jumlah daun jagung varietas lokal Tambin sebanyak 14 helai. Pada penelitian Ningsih et al. (2015) perlakuan pupuk kotoran ayam menghasilkan jumlah daun terbanyak yaitu sebesar 10,46 helai. Hal ini menunjukkan bahwa pupuk kotoran ayam dapat menyediakan berbagai unsur hara makro maupun mikro yang dibutuhkan tanaman untuk dapat tumbuh optimal. Proses pembentukan daun dipengaruhi oleh tersedianya unsur hara nitrogen $(\mathrm{N})$ dan fosfor $(\mathrm{P})$ yang siap diserap oleh tanaman. Kedua unsur ini berperan membentuk selsel baru dan merupakan komponen utama penyusun senyawa organik seperti ADP dan ATP, asam amino, asam nukleat, dan juga klorofil (Oviyanti dan Hidayah 2016). Tercukupinya unsur nitrogen juga mendorong proses pertumbuhan dan perkembangan daun serta mendorong pertumbuhan vegetatif tanaman. Pupuk kotoran ayam juga dapat menyediakan beberapa unsur mikro seperti $\mathrm{Zn}$, Mo, Cu, dan Si (Aditiameri, 2016).

Aplikasi pupuk kotoran kambing menghasilkan diameter batang jagung Tambin sebesar 19,26 mm. Sejalan dengan penelitian Syafruddin et al. (2012), aplikasi pupuk kandang dapat menghasilkan diameter batang jagung manis sebesar 20,71 mm. Perbedaan 
diameter batang disebabkan adanya aktivitas pembelahan dan perbesaran sel pada meristem lateral yang mengakibatkan diameter batang bertambah. Ketersediaan unsur hara yang mencukupi bagi tanaman merupakan faktor utama yang akan mempengaruhi pertumbuhan dan perkembangan tanaman, dan akhirnya akan mempengaruhi pertambahan pembesaran sel yang berpengaruh pada diameter batang (Klau et al. 2019).

Pada fase vegetatif, unsur $\mathrm{N}$ memegang peran penting bagi pertumbuhan tanaman. Tanggapan pertumbuhan jagung di atas tanah, seperti tinggi tanaman, diameter batang, luas daun, dan pertumbuhan akar dipengaruhi oleh pengaplikasian pupuk organik. Pengaplikasian sumber bahan organik akan menghasilkan efek yang setara atau lebih baik pada pertumbuhan, perkembangan dan juga produksi tanaman (Lin et al. 2018). Kurangnya unsur hara makro dan mikro yang terserap juga mempengaruhi pertumbuhan vegetatif tanaman khususnya diameter batang jagung varietas Tambin. Pemberian bahan organik dapat meningkatkan ketersediaan unsur hara dalam tanah, terutama unsur $\mathrm{N}$ yang berfungsi untuk perkembangan vegetatif tanaman (Nurcahya et al. 2017). Dengan tercukupi kebutuhan unsur-unsur hara tanaman maka tinggi tanaman, jumlah dan juga diameter batang akan semakin meningkat. Menurut (Adviany dan Maulana 2019), pertumbuhan tinggi tanaman meningkat seiring dengan bertambahnya pemberian bahan organik sebagai sumber nutrisi bagi pertumbuhan.

Tabel 2 menunjukkan tanggapan jagung terhadap beberapa jenis pupuk organik pada 9 MST yang mampu meningkatkan pertumbuhan panjang, lebar, dan sudut daun. Berdasarkan hasil analisis ragam, diketahui bahwa pemberian berbagai pupuk organik berpengaruh nyata pada lebar daun, namun tidak berpengaruh nyata pada panjang dan sudut daun. Pupuk kompos mampu menghasilkan lebar daun tertinggi, namun tidak berbeda nyata dengan pupuk kotoran sapi, pupuk urine kelinci, pupuk kotoran ayam dan pupuk kotoran kambing.

Panjang daun jagung Tambin lebih tinggi di seluruh perlakuan kecuali pupuk kotoran ayam jika dibandingkan dengan kontrol. Panjang daun jagung Tambin dapat mencapai 86,25 cm pada pupuk kompos. Hasil penelitian Liu et al. (2014) menunjukkan bahwa aplikasi kompos, dapat meningkatkan panjang daun sebesar 38 - 61\%. Aplikasi berbagai pupuk organik menghasilkan sudut daun lebih kecil jika dibandingkan kontrol pada seluruh perlakuan kecuali pada pupuk kompos dan urine kelinci. Lebar daun terbesar dihasilkan oleh perlakuan pupuk kompos dengan lebar daun sebesar $6,48 \mathrm{~cm}$ dan lebar daun terkecil dihasilkan pada kontrol. Hasil penelitian ini sejalan dengan hasil penelitian Imas et al. (2017) yang menyatakan bahwa penggunaan pupuk kompos dapat meningkatkan pertumbuhan lebar daun cabai. Menurut Aditiameri (2016) penggunaan pupuk kotoran ayam juga meningkatkan lebar daun pakcoy. Aplikasi pupuk organik dalam bentuk pupuk kandang dan kompos mampu meningkatkan pertumbuhan hasil dan kualitas kangkung akuaponik dibandingkan dengan tanpa aplikasi pupuk organik (Rahmi et al. 2016).

Tabel 2. Tanggapan jagung varietas lokal Tambin terhadap pupuk organik pada panjang, lebar dan sudut daun umur 9 MST

\begin{tabular}{lccc}
\hline Pupuk Organik & $\begin{array}{c}\text { Panjang } \\
\text { daun } \\
(\mathrm{cm})\end{array}$ & $\begin{array}{c}\text { Lebar } \\
\text { daun } \\
(\mathrm{cm})\end{array}$ & $\begin{array}{c}\text { Sudut } \\
\text { daun } \\
\left({ }^{\circ}\right)\end{array}$ \\
\hline Tanpa pupuk organik & 78,19 & $4,81 \mathrm{c}$ & 58,13 \\
Pupuk organik cair & 86,15 & $5,34 \mathrm{cb}$ & 49,63 \\
Kompos & 86,25 & $6,48 \mathrm{a}$ & 63,25 \\
Kotoran sapi & 82,04 & $5,68 \mathrm{abc}$ & 51,00 \\
Urine kelinci & 82,94 & $5,59 \mathrm{abc}$ & 61,00 \\
Kotoran ayam & 77,99 & $5,91 \mathrm{ab}$ & 48,38 \\
Kotoran kambing & 79,39 & $6,04 \mathrm{ab}$ & 57,75 \\
\hline
\end{tabular}

Keterangan: Angka yang diikuti huruf yang sama pada kolom yang sama menunjukkan tidak berbeda nyata pada DMRT taraf $5 \%$.

Pupuk kandang merupakan sumber nitrogen yang memberikan pengaruh cepat pada pertumbuhan tanaman. Pupuk kandang juga sumber beberapa hara seperti nitrogen, fosfor, kalium, dan lainnya (Aditiameri, 2016). Aplikasi berbagai jenis pupuk organik menunjukkan tanggapan yang tidak berbeda nyata pada bobot daun khas 3 dan 6 MST, namun nyata pada luas daun tanaman 3 MST (Tabel 3).

Tabel 3. Tanggapan jagung lokal Tambin terhadap pupuk organik pada luas daun per tanaman dan bobot daun khas per tanaman

\begin{tabular}{lcccr}
\hline \multirow{2}{*}{ Pupuk Organik } & \multicolumn{2}{c}{ Luas daun $\left(\mathrm{cm}^{2}\right)$} & \multicolumn{2}{c}{ Bobot Daun Khas $\left(\mathrm{g} . \mathrm{cm}^{2}\right)$} \\
\cline { 2 - 5 } & $3 \mathrm{MST}$ & $6 \mathrm{MST}$ & $3 \mathrm{MST}$ & $6 \mathrm{MST}$ \\
\hline Tanpa pupuk organik & $651,51 \mathrm{~b}$ & 2578,07 & 0,0021 & 0,0036 \\
Pupuk organik cair & $501,29 \mathrm{~b}$ & 2668,66 & 0,0026 & 0,0037 \\
Kompos & $1367,64 \mathrm{a}$ & 3290,20 & 0,0135 & 0,0034 \\
Kotoran sapi & $1572,49 \mathrm{a}$ & 2873,84 & 0,0030 & 0,0037 \\
Urine kelinci & $445,33 \mathrm{~b}$ & 2444,17 & 0,0023 & 0,0036 \\
Kotoran ayam & $1380,96 \mathrm{a}$ & 2762,59 & 0,0035 & 0,0046 \\
Kotoran kambing & $1738,03 \mathrm{a}$ & 3047,71 & 0,0039 & 0,0041
\end{tabular}

Keterangan: Angka yang diikuti huruf yang sama pada kolom yang sama menunjukkan tidak berbeda nyata pada DMRT taraf $5 \%$. 
Berdasarkan Tabel 3, pada 3 MST luas daun tertingg dihasilkan oleh perlakuan pupuk kotoran kambing dengan luas daun sebesar $1738,03 \mathrm{~cm}$ namun tidak berbeda nyata dengan pupuk kompos, pupuk kotoran sapi dan pupuk kotoran ayam. Hal ini sejalan dengan penelitian (Krisnadhi et al. 2020) yang menyatakan hasil luas daun pada pupuk kotoran kambing dapat mencapai $5935,34 \mathrm{~cm}$ yang merupakan luas daun tertinggi dari perlakuan lainnya. Luas permukaan daun juga sangat dipengaruhi oleh ketersediaan unsur hara. Tanaman yang tinggi dan memiliki daun yang luas berarti tercukupi kebutuhan unsur haranya (Puspadewi et al. 2016). Semakin luas permukaan daun, maka proses penangkapan sinar matahari dan fiksasi $\mathrm{CO} 2$ makin tinggi sehingga proses fotosintesis berjalan dengan baik dan fotosintat yang dihasilkan semakin banyak (Sari et al. 2016).

Hasil penelitian ini menunjukkan bahwa pada 3 dan 6 MST, tanggapan jagung terhadap aplikasi berbagai pupuk organik adalah tidak nyata pada bobot daun khas jagung Tambin. Pada 3 MST seluruh perlakuan memberikan bobot daun khas lebih tinggi jika dibandingkan kontrol dan pada 6 MST seluruh perlakuan kecuali pupuk kompos memberikan bobot daun khas lebih tinggi jika dibandingkan kontrol. Hal ini sejalan dengan penelitian (El-Shafey dan El-Hawary 2016) yang menunjukkan bahwa semakin banyak tingkat kandungan pupuk organik maka bobot daun khas akan semakin tinggi, hal ini dapat disebabkan oleh kandungan bahan organik yang tersedia lebih lama di dalam tanah karena bahan organik ini secara bertahap disediakan oleh pupuk organik. Tanah dengan tambahan kandungan bahan organik yang tinggi akan mempunyai sifat fisik, kimia dan biologi tanah yang lebih baik maka pertumbuhan dan perkembangan tanaman juga akan terdukung (Puspadewi et al. 2016).

Efisiensi proses fotosintesis untuk membentuk berbagai jaringan dan organ tanaman dapat dilihat dengan laju asimilasi bersih. Laju asimilasi erat kaitannya dengan proses fotosintesis (Widyaswari et al. 2017). Laju asimilasi bersih tinggi maka kemampuan daun menghasilkan fotosintat akan semakin besar dan akan meningkatkan produksi tanaman (Ekamaida 2016). Sedangkan laju pertumbuhan relatif merupakan refleksi dari akumulasi bobot kering pada periode tertentu. Laju pertumbuhan relatif yang tinggi dapat diperoleh karena tanaman mendapatkan ketersediaan unsur hara yang tinggi, yang akan mempengaruhi berbagai pertumbuhan dan perkembangan organ tanaman (Rasool et al. 2015). Hasil analisis ragam menunjukkan tanggapan yang tidak nyata terhadap berbagai pupuk organik pada kandungan klorofil, laju asimilasi bersih dan laju pertumbuhan relatif jagung Tambin (Tabel 4).

Berdasarkan Tabel 4, kandungan klorofil a, klorofil b, klorofil total, laju asimilasi bersih dan laju pertumbuhan relatif jagung Tambin tidak berbeda nyata antara yang diberi pupuk organik maupun tanpa pemberian pupuk organik. Hal ini menunjukkan bahwa dalam penelitian ini pemberian berbagai pupuk organik belum dapat meningkatkan beberapa parameter tersebut. Hal ini diduga karena kandungan unsur hara yang ada dalam pupuk organik tersebut belum mencukupi sehingga belum mampu meningkatkan kandungan klorofil a, klorofil b, klorofil total, LAB dan LPR jagung Tambin. Nitrogen dan Magnesium merupakan unsur hara esensial yang dibutuhkan oleh tanaman. Magnesium berfungsi sebagai konstituen mineral utama pada molekul klorofil, membantu tanaman untuk membentuk gula dan pati, berperan dalam translokasi fosfor dan membantu fungsi enzim tanaman. Mg juga memiliki fungsi dalam proses distribusi fotosintat, aktivator ANR dan RuBP karboksilase. Nitrogen banyak ditemukan dalam organ tanaman berfungsi dalam pembentukan klorofil, asam amino, protein, dan asam nukleat (Marschner 2012). Apabila kebutuhan tanaman tidak tercukupi maka pertumbuhan dan perkembangan tanaman tidak optimal

Klorofil merupakan faktor utama yang mempengaruhi fotosintesis (Song dan Banyo 2011). Kandungan klorofil daun merupakan salah satu indikator aktivitas fotosintesis berkaitan dengan konsentrasi $\mathrm{N}$ pada tumbuhan segar dan berfungsi sebagai tolak ukur respons tanaman terhadap ketersediaan $\mathrm{N}$ di tanah (Naeem et al. 2018). Tabel 4 menunjukkan bahwa pemberian berbagai pupuk organik tidak berpengaruh nyata terhadap kandungan klorofil $a, b$ dan total daun jagung Tambin.

Dalam penelitian ini, kandungan klorofil a berkisar dari 0,472-0,490 dengan perlakuan pupuk kompos dan pupuk kotoran kambing memiliki nilai klorofil a lebih tinggi jika dibandingkan dengan kontrol, data kandungan klorofil b berkisar dari 0,581-0,815 dengan perlakuan pupuk organik cair dan pupuk urine kelinci memiliki nilai klorofil b lebih tinggi jika dibandingkan dengan kontrol, dan klorofil total jagung Tambin dapat mencapai nilai 1,289 pada perlakuan pupuk urine kelinci. Hal ini menunjukkan bahwa kandungan klorofil a, b dan total pada daun jagung Tambin yang diberi pupuk organik memiliki kandungan klorofil sama dengan perlakuan tanpa pemberian pupuk organik. Sinuraya dan Melati (2019) menyatakan bahwa pemberian pupuk kandang pada jagung manis sebesar 20 ton.ha- ${ }^{-1}$ menghasilkan kandungan klorofil a dan klorofil $b$ masing-masing sebesar 2,38 dan $0,77 \mathrm{mg}^{-1} \mathrm{~g}^{-1}$.

Pengukuran bobot kering tanaman dilakukan sebanyak 3 kali yaitu pada 3,6 dan 13 MST (saat panen). Tanggapan jagung Tambin terhadap berbagai pupuk organik adalah nyata pada bobot kering tanaman jagung Tambin (Tabel 5). Hal ini menunjukkan bahwa kandungan nutrisi pada berbagai pupuk organik dapat mencukupi kebutuhan untuk pertumbuhan dan perkembangan tanaman. Jika ketersediaan nutrisi tercukupi maka hasil fotosintesis tanaman akan meningkat begitu pula dengan bobot kering tanaman tersebut juga akan meningkat. 
Tabel 4. Tanggapan jagung lokal Tambin terhadap pupuk organik pada kandungan klorofil a, klorofil b, klorofil total, laju asimilasi bersih dan laju pertumbuhan relatif

\begin{tabular}{lccccc}
\hline Pupuk Organik & Klorofil a & Klorofil b & Klorofil total & $\begin{array}{c}\text { Laju Asimilasi } \\
\text { Bersih } \\
\left(\mathrm{g} . \mathrm{cm}^{-2} \text { per minggu }\right)\end{array}$ & $\begin{array}{c}\text { Laju Pertumbuhan } \\
\text { Relatif } \\
\text { (g.g-1 per hari) }\end{array}$ \\
\hline Tanpa pupuk organik & 0,485 & 0,744 & 1,225 & 0,000765 & 0,07046 \\
Pupuk organik cair & 0,484 & 0,805 & 1,280 & 0,000983 & 0,08599 \\
Kompos & 0,486 & 0,727 & 1,211 & 0,001371 & 0,05832 \\
Kotoran sapi & 0,481 & 0,699 & 1,180 & 0,000742 & 0,02690 \\
Urine kelinci & 0,472 & 0,815 & 1,289 & 0,001261 & 0,08637 \\
Kotoran ayam & 0,476 & 0,737 & 1,218 & 0,000631 & 0,03321 \\
Kotoran kambing & 0,490 & 0,581 & 1,074 & 0,000554 & 0,02752 \\
\hline
\end{tabular}

Keterangan: Angka yang diikuti huruf yang sama pada kolom yang sama menunjukkan tidak berbeda nyata pada DMRT taraf $5 \%$.

Tabel 5. Tanggapan jagung varietas lokal Tambin terhadap berbagai pupuk organik pada bobot kering tanaman

\begin{tabular}{lccc}
\hline \multirow{2}{*}{ Pupuk Organik } & \multicolumn{3}{c}{ Bobot kering tanaman $(\mathrm{g})$} \\
\cline { 2 - 4 } & $3 \mathrm{MST}$ & $6 \mathrm{MST}$ & Panen \\
\hline Tanpa pupuk organik & $1,95 \mathrm{~b}$ & $23,37 \mathrm{~b}$ & $39,71 \mathrm{c}$ \\
Pupuk organik cair & $2,36 \mathrm{~b}$ & $26,41 \mathrm{~b}$ & $42,68 \mathrm{c}$ \\
Kompos & $8,64 \mathrm{a}$ & $58,2 \mathrm{a}$ & $76,52 \mathrm{a}$ \\
Kotoran sapi & $7,27 \mathrm{a}$ & $42,54 \mathrm{ab}$ & $54,07 \mathrm{ab}$ \\
Urine kelinci & $1,69 \mathrm{~b}$ & $30,24 \mathrm{~b}$ & $58,26 \mathrm{~b}$ \\
Kotoran ayam & $7,88 \mathrm{a}$ & $32,58 \mathrm{~b}$ & $61,38 \mathrm{~b}$ \\
Kotoran kambing & $10,09 \mathrm{a}$ & $37,01 \mathrm{~b}$ & $61,14 \mathrm{~b}$ \\
\hline
\end{tabular}

Keterangan: Angka yang diikuti huruf yang sama pada kolom yang sama menunjukkan tidak berbeda nyata pada DMRT taraf $5 \%$.

Dalam penelitian ini, kandungan klorofil a berkisar dari 0,472-0,490 dengan perlakuan pupuk kompos dan pupuk kotoran kambing memiliki nilai klorofil a lebih tinggi jika dibandingkan dengan kontrol, data kandungan klorofil b berkisar dari 0,581-0,815 dengan perlakuan pupuk organik cair dan pupuk urine kelinci memiliki nilai klorofil b lebih tinggi jika dibandingkan dengan kontrol, dan klorofil total jagung Tambin dapat mencapai nilai 1,289 pada perlakuan pupuk urine kelinci. Hal ini menunjukkan bahwa kandungan klorofil $a$, $b$ dan total pada daun jagung Tambin yang diberi pupuk organik memiliki kandungan klorofil sama dengan perlakuan tanpa pemberian pupuk organik. Sinuraya dan Melati (2019) menyatakan bahwa pemberian pupuk kandang pada jagung manis sebesar 20 ton.ha ${ }^{-1}$ menghasilkan kandungan klorofil a dan klorofil b masing-masing sebesar 2,38 dan 0,77 mg. $\mathrm{g}^{-1}$.

Pengukuran bobot kering tanaman dilakukan sebanyak 3 kali yaitu pada 3, 6 dan 13 MST (saat panen). Tanggapan jagung Tambin terhadap berbagai pupuk organik adalah nyata pada bobot kering tanaman jagung Tambin (Tabel 5). Hal ini menunjukkan bahwa kandungan nutrisi pada berbagai pupuk organik dapat mencukupi kebutuhan untuk pertumbuhan dan perkembangan tanaman. Jika ketersediaan nutrisi tercukupi maka hasil fotosintesis tanaman akan meningkat begitu pula dengan bobot kering tanaman tersebut juga akan meningkat.
Berdasarkan Tabel 5, pengamatan bobot kering pada 3, 6, dan 13 MST (saat panen) menunjukkan bahwa aplikasi pupuk kompos mampu menghasilkan bobot kering tanaman paling tinggi dibandingkan pupuk organik yang lainnya dengan bobot kering sebesar 8,64 $\mathrm{g}, 58,2 \mathrm{~g}$ dan $76,52 \mathrm{~g}$, namun tidak berbeda nyata dengan pupuk kotoran kambing. Hasil penelitian ini sejalan dengan Manolikaki dan Diamadopoulos (2019) yang menyatakan pengaplikasian pupuk kompos dapat meningkatkan berat kering tanaman minimal $75 \%$. Aplikasi pupuk organik dapat meningkatkan bobot kering tanaman karena aplikasi pupuk organik ke dalam tanah akan memperbaiki struktur dan pori-pori tanah. Hal ini akan memberikan aerasi yang baik dan menyebabkan meningkatnya kandungan oksigen serta dapat menahan serapan air dan unsur hara yang dapat diserap oleh tanaman agar dapat berkembang dengan optimal sehingga perkembangan tanaman menjadi lebih baik (Putra et al. 2015). Pertumbuhan dan perkembangan tanaman memerlukan nutrisi dalam jumlah yang cukup agar bisa efektif. Pemberian pupuk organik dapat meningkatkan serapan hara tanaman, terutama unsur $\mathrm{N}$, untuk memacu proses pertumbuhan dan perkembangan tanaman yang akan mempengaruhi pertumbuhan fase vegetatif tanaman dan meningkatkan laju fotosintesis (Baharuddin 2016). Peningkatan laju fotosintesis akan meningkatkan hasil fotosintat sehingga berat kering tanaman akan juga meningkat. 


\section{KESIMPULAN}

Tanggapan jagung varietas lokal Tambin terhadap berbagai pupuk organik adalah tidak signifikan pada morfologis jagung, meliputi tinggi tanaman, jumlah daun, diameter batang, panjang dan sudut daun jagung Tambin. Aplikasi kompos, pupuk kotoran sapi, kotoran ayam, dan kotoran kambing dapat meningkatkan luas daun umur 3 MST sebesar 716,13-1086,52 g per tanaman. Pada karakter fisiologis, aplikasi berbagai pupuk organik belum dapat meningkatkan laju asimilasi bersih, laju pertumbuhan relatif, kandungan klorofil dan bobot daun khas jagung Tambin. Pemberian semua pupuk organik, kecuali pupuk organik cair meningkatkan bobot kering tanaman pada saat panen sebesar 2,97$36,81 \mathrm{~g}$.

\section{UCAPAN TERIMA KASIH}

Tim Peneliti menyampaikan banyak terima kasih kepada Lembaga Penelitian dan Pengabdian Masyarakat Universitas Sebelas Maret Surakarta atas pendanaan PNBP tahun anggaran 2020 dengan nomor kontrak: 452/UN27.21/PN/2020 yang telah diberikan sehingga kegiatan penelitian ini dapat berjalan lancar.

\section{DAFTAR PUSTAKA}

Adijaya IN, Yasa IMR. 2014. Pengaruh pupuk organik terhadap sifat tanah, pertumbuhan dan hasil jagung.. Dalam: Yasin M, Noor A, Galib R, Suryana, Rohaeni ES, Hasbianto A. Agro inovasi mendukung pertanian industrial unggul berkelanjutan berbasis sumber daya lokal. Prosiding Seminar Nasional Inovasi Teknologi Pertanian Spesifik Lokasi; 6-7 Agustus 2014 Banjarbaru (ID): BPTP Kalsel. pp. 299-310.

Aditiameri A. 2016. Respon pemberian macam pupuk organik dan dosis pupuk daun terhadap pertumbuhan dan hasil tanaman pakcoy (Brassica rapa L.). AGRISIA J IImu IImu Pertan. 8(2):113-127.

Adviany I, Maulana DD. 2019. Pengaruh pupuk organik dan jarak tanam terhadap C-organik, populasi jamur tanah dan bobot kering akar serta hasil padi sawah pada inceptisols Jatinangor, Sumedang. Agrotechnology Res J. 3(1):28-35. https://dx.doi.org/10.20961/agrotechresj.v3i1.30382.

Amzeri A. 2009. Penampilan lima kultivar jagung Madura. Agrovigor 2(1): 23-30.

Amzeri A. 2018. Tinjauan perkembangan pertanian jagung di madura dan alternatif pengolahan menjadi biomaterial. Jurnal IImiah Rekayasa. 11(1): 74-86. https://doi.org/10.21107/rekayasa.v11i1.4127.

Arifin Z, Fatmawati. 2011. Pemurnian dan pengembangan jagung varietas manding, talango dan guluk-guluk di Kabupaten Sumenep. Dalam: Prosiding Seminar Nasional Serealia 2011. Bogor (ID): Balitbang Serealia, Litbang Pertanian Permentan RI .103-112

Asrori H, Siswadi, Sumarmi. 2019. Kajian macam pupuk kandang terhadap pertumbuhan dan hasil tiga varietas kedelai. J Inov Pertan. 21(1):14-21.
Baharuddin R. 2016. Respon pertumbuhan dan hasil tanaman cabai (Capsicum annum L.) terhadap pengurangan dosis NPK 16: 16: 16 dengan pemberian pupuk organik. J Din Pertan. 32(2):115-124.

Dinariani, Heddy YBS, Guritno B. 2010. Kajian penambahan pupuk kandang kambing dan kerapatan tanaman yang berbeda pada pertumbuhan dan hasil tanaman jagung manis (Zea mays saccharata Sturt). J Prod Tanam. 2(2):128-136.

Ekamaida. 2016. Pengaruh penambahan natrium benzoat dan lama penyimpanan pada $\mathrm{PH}$ sari buah tomat (Solanum lycopersicum L.). J Agrium. 13(1):24-26.

El-Shafey Al, El-Hawary MM. 2016. Integrated effect of bio-organic and/or nitrogen fertilizer on growth and yield of maize (Zea mays L.). Zagazig J Agric Res. 43(4):1105-1119.

https://doi.org/10.21608/zjar.2016.100480.

Fitriasari C, Rahmayuni E. 2017. Efektivitas pemberian urin kelinci untuk mengurangi dosis pupuk anorganik pada budidaya putren jagung manis. J Agrosains Teknologi 2(2): 141-156.

Gomez AK, Gomez AA. 1995. Prosedur statistik untuk penelitian pertanian. Penerjemah Sjamsudin E, Baharsjah JS. Jakarta (ID): UI Press. 698p.

Imas S, Damhuri, Munir A. 2017. Pengaruh pemberian pupuk kompos terhadap produktivitas tanaman cabai merah (Capsicum annuum L.). J Ampibi. 2(1):57-64.

Islam MS, Hasanuzzaman M, Rokonuzzaman M, Nahar K. 2009. Effect of split application of nitrogen fertilizer on morphophysiological parameters of rice genotypes. Int J Plant Prod. 3(1): 51-62.

Klau P, Sio S, Bani PW. 2019. Aplikasi pupuk Bokashi padat berbahan dasar feses babi dengan level berbeda terhadap pertumbuhan tanaman sengon laut (Paraserianthes falcataria (L.) Nielsen). J Anim Sci. 4(2):15-17. https://doi.org/10.32938/ja.v4i2.644.

Krisnadhi JD, Yurlisa K, Sudiarso. 2020. Pengaruh pemberian Plant Growth Promoting Rhizobacteria (PGPR) dan dosis pupuk kandang kambing terhadap pertumbuhan dan hasil jagung manis (Zea mays $L$. var. Saccharata). J Prod Tanam. 8(2):234-240.

Leki W, Lelang MA, Taolin RICO. 2016. Pengaruh takaran pupuk kandang sapi terhadap pertumbuhan dan hasil jagung (Zea mays L.) yang ditumpangsarikan dengan kedelai (Glysine max (L.) Merril). Savana Cendana. 1(1):17-23. https://doi.org/10.32938/sc.v1i01.4.

Lesilolo MK. 2012. Studi pemupukan fosfat terhadap viabilitas dan vigor benih jagung (Zea mays L.) varietas hulaliu. Agrologia. 1(2):119-125. https://doi.org/10.30598/a.v1i2.287.

Lin Y, Watts DB, Kloepper JW, Torbert HA. 2018. Influence of Plant Growth-Promoting Rhizobacteria on corn growth under different fertility sources. Commun Soil Sci Plant Anal. 49(10):1239-1255. https://doi.org/10.1080/00103624.2018.1457155. 
Liu CW, Sung Y, Chen BC, Lai HY. 2014. Effects of nitrogen fertilizers on the growth and nitrate content of lettuce (Lactuca sativa L.). Int J Environ Res Public Health. 11(4):4427-4440. https://doi.org/10.3390/ijerph110404427.

Manolikaki I, Diamadopoulos E. 2019. Positive effects of biochar and biochar-compost on maize growth and nutrient availability in two agricultural soils. Commun Soil Sci Plant Anal. 50(5):512-526. https://doi.org/10.1080/00103624.2019.1566468.

Marschner H. 2012. Mineral nutrition of higher plants. 3rd Editions. London (GB): Academic Press.

Naeem MA, Khalid M, Aon M, Abbas G, Amjad M, Murtaza B, Khan W, Ahmad N. 2018. Combined application of biochar with compost and fertilizer improves soil properties and grain yield of maize. J Plant Nutr. 41(1):112-122. https://doi.org/10.1080/01904167.2017.1381734.

Ningsih ND, Marlina N, Hawayanti E. 2015. Pengaruh jenis pupuk organik terhadap pertumbuhan dan produksi beberapa varietas jagung manis (Zea mays saccharata Sturt). Klorofil. 10(2):93-100.

Nurcahya AO, Herlina N, Guritno B. 2017. Pengaruh macam pupuk organik dan waktu aplikasi terhadap pertumbuhan dan hasil jagung manis (Zea mays saccharata Sturt). J Prod Tanam 5(9):1476-1482.

Oviyanti F, Syarifah, Hidayah N. 2016. Pengaruh pemberian pupuk organik cair daun gamal (Gliricidia sepium (Jacq.) Kunth ex Walp.) terhadap pertumbuhan tanaman sawi (Brassica juncea L.). J Biota. 2(1):61-67.

Puspadewi S, Sutari W, Kusumiyati K. 2016. Pengaruh konsentrasi pupuk organik cair (POC) dan dosis pupuk N, P, K terhadap pertumbuhan dan hasil tanaman jagung manis (Zea mays L. var Rugosa Bonaf) kultivar talenta. J Kultivasi. 15(3):208-216. https://doi.org/10.24198/kltv.v15i3.11764.

Putra AD, Damanik MM B, Hanum H. 2015. Aplikasi pupuk urea dan pupuk kandang kambing untuk meningkatkan n-total pada tanah Inceptisol Kwala Bekala dan kaitannya terhadap pertumbuhan tanaman jagung. J Online Agrotek 3(2337):128-135.

Rahmi A, Jumiati D. 2007. Pengaruh konsentrasi dan waktu penyemprotan pupuk organik cair super $\mathrm{ACI}$ terhadap pertumbuhan dan hasil jagung manis. $J$ Agritop. 26(3):105-109.

Rahmi S, Prajitno D, Indradewa D. 2016. Pengaruh komposisi pupuk kandang dan kompos terhadap pertumbuhan dan hasil kangkung (Ipomea reptans) akuaponik. J Teknologi Lingkungan. 17(2):108-117. https://doi.org/10.29122/jtl.v17i2.111.
Rasool S, Kanth R, Hamid S, Raja W, Alie B, Dar Z. 2015. Influence of integrated nutrient management on growth and yield of sweet corn (Zea mays L. saccharata) under temperate conditions of Kashmir Valley. Am J Exp Agric. 7(5):315-325.

Safitri MD, Hendarto K, Hidayat KF, Sunyoto. 2017. Pengaruh dosis pupuk kandang kambing dan pupuk hayati terhadap pertumbuhan dan hasil jagung (Zea mays L.). J Agrotek Trop. 5 (2): 75-79. http://dx.doi.org/10.23960/jat.v5i2.1830.

Santosa E. 2012. Rice organic farming is a programme for strengtenning food security in sustainable rural development. Int J Basic Appl Sci. 1:1-6.

Sari RMP, Maghfoer MD, Koesriharti. 2016. Pengaruh frekuensi penyiraman dan dosis pupuk kandang ayam terhadap pertumbuhan dan hasil tanaman pakchoy (Brassica rapa L. var. chinensis. J Prod Tanam. 4(5):342-351.

Silalahi MJ, Rumambi A, Telleng MM, Kaunang WB. 2018. Pengaruh pemberian pupuk kandang ayam terhadap pertumbuhan tanaman sorgum sebagai pakan. Zootec 38(2):286-295. https://doi.org/10.35792/zot.38.2.2018.19909.

Sinuraya BA, Melati M. 2019. Pengujian berbagai dosis pupuk kandang kambing untuk pertumbuhan dan produksi jagung manis organik (Zea mays var. Saccharata Sturt). Bul Agrohorti. 7(1):47-52. https://doi.org/10.29244/agrob.v7i1.24407.

Sitompul S.M. 2016 Analisis pertumbuhan tanaman. Malang (ID): UB Press.

Suhardjo, Lestari, IE. 2006. Pengkajian pengaruh beberapa varietas jagung terhadap mutu tortila. Malang (ID): Balai Pengkajian Teknologi Pertanian Jawa Timur

Song AN, Banyo Y. 2011. Konsentrasi klorofil daun sebagai indikator kekurangan air pada tanaman. J IIm Sains. https://doi.org/10.35799/jis.11.2.2011.202.

Syafruddin S, Nurhayati N, Wati R. 2012. Pengaruh jenis pupuk terhadap pertumbuhan dan hasil beberapa varietas jagung manis. J Floratek. 7(1):107-114.

Syah MJA, Santoso PJ, Usman F, Purnama T. 2003. Hubungan laju pertumbuhan dengan saat berbunga untuk seleksi kegenjahan tanaman pepaya. J Hortik. 13(3):182-189.

Widyaswari E, Santosa M, Maghfoer MD. 2017. Analisis pertumbuhan dua varietas tanaman padi (Oryza sativa L.) pada berbagai perlakuan pemupukan. Biotropika J Biotropika. 5(3):73-77. http://dx.doi.org/10.21776/ub.biotropika.2017.005.03.2. 